J. Clin. Chem. Clin. Biochem.

Vol. 23, 1985, pp. 447-452

\title{
Catecholamines in the Plasma and Urine of Patients with Alcoholic Liver Damage under Resting and Exercise Conditions ${ }^{1}$ )
}

\author{
By D. Ratge, Gabriele Brugger ${ }^{2}$ ) \\ Abteilung für Klinische Chemie, Robert-Bosch-Krankenhaus Stuttgart \\ M. Wehr
}

Zentrum für Innere Medizin, Universität Marburg

J. Ch. Bode

Abteilung für Gastroenterologie und Endokrinologie, Robert-Bosch-Krankenhaus Stuttgart and

H. Wisser

Abteilung für Klinische Chemie, Robert-Bosch-Krankenhaus Stuttgart .

(Received September 20/November 1, 1984/May 6, 1985)

Summary: Heart rate and plasma catecholamines were determined in 16 patients with alcoholic fatty liver and 14 patients with alcoholic cirrhosis of the liver. The measurements were performed at rest and after exercise on the bicycle ergometer, on average 11 days after admission to hospital. In comparison with a control group, the mean heart rate of the patient group was significantly increased at rest and under graduated loading. Significantly increased plasma catecholamine concentrations under resting conditions were observed in both groups of patients, the increase being more pronounced in the cirrhotics (increased with progressive liver damage, significant differences being found between the control group and each of the two groups of patients). During exercise under a load of 50 or 100 watts, the increases in adrenaline, noradrenaline and dopamine concentrations were greatest in patients with alcoholic cirrhosis. With reference to the initial values, however, the increases in concentration were identical in all three groups.

In the patients, metabolism of the catecholamines remained unchanged after an average of 11 days abstinence from alcohol; they showed a significantly diminished elimination of vanillylmandelic acid in the urine and, compared with the greatly elevated plasma catecholamine levels, they showed only a moderate increase in the excretion of catecholamines. The results reported here support the assumption that changes in catecholamine metabolism compatible with an increased sympathetic activity are present in chronic alcoholics without advanced liver damage.

Plasma- und Urinkatecholamine in Ruhe und unter Belastung bei Patienten mit alkoholischer Leberschädigung

Zusammenfassung: Bei 16 Patienten mit alkoholischer Fettleber und 14 Patienten mit Alkoholcirrhose wurden im Mittel 11 Tage nach Klinikaufnahme die Herzfrequenz und die Plasmakatecholamine in Ruhe und nach Fahrradergometrie bestimmt. Im Vergleich zu einer Kontrollgruppe war die mittlere Herzfrequenz bei beiden Patientenkollektiven in Ruhe und unter dosierter Belastung signifikant erhöht. Signifikant erhöhte Katecholaminkonzentrationen im Plasma unter Ruhebedingungen wurden in beiden Patientengruppen beob-

1) This study was supported by the Robert Bosch foundation, Stuttgart (F.R.G.).

2) This paper contains parts of the doctoral thesis of Gabriele Brugger.

J.Clin. Chem. Clin. Biochem. / Vol. 23, 1985 / No. 8 
achtet, wobei der Anstieg bei den Cirrhotikern am ausgeprägtesten war. Während der Belastung mit 50 und 100 Watt waren die Anstiege der Adrenalin-, Noradrenalin- und Dopaminkonzentrationen bei den Patienten mit Alkoholcirrhose am höchsten. Auf die Ausgangswerte bezogen waren die Konzentrationserhöhungen in allen drei Kollektiven allerdings identisch.

Die Metabolisierung der Katecholamine ist bei den Patienten nach durchschnittlicher Alkoholabstinenz von 11 Tagen weiterhin verändert. So wurde eine gegenüber der Kontrollgruppe signifikant verminderte Ausscheidung der Vanillinmandelsäure und eine im Vergleich zu den stark erhöhten Katecholaminkonzentrationen im Plasma nur mäßig erhöhte Katecholaminausscheidung nachgewiesen. Unsere Ergebnisse bestätigen die Annahme, daß Änderungen des Katecholaminstoffwechsels - im Einklang mit einer erhöhten Sympathicusaktivität - schon bei chronischen Alkoholikern ohne fortgeschrittenen Leberschaden auftreten.

\section{Introduction}

Alcohol ingestion, whether acute or chronic, brings a change in the function of most endocrine organs in humans (1). Data in the literature on the influence of alcohol on catecholamine metabolism are inconsistent. Following the acute administration of high doses of alcohol, unchanged (2) and elevated (3) quantities of adrenaline and noradrenaline have been reported in the urine. Chronic alcohol consumption has been reported to stimulate the sympathetic nervous system leading to elevated plasma catecholamine concentrations and raised excretion of catecholamines in the urine $(4,5)$. However, in alcoholics who remained abstinent for more than 1 week, no differences were seen in the catecholamine excretion in 24-hour urine vis-á-vis control subjects not drinking alcohol (2).

The aim of the present study was to determine the behaviour of the plasma concentration of the catecholamines under resting conditions and under graduated loading in a large random sample of chronic alcoholics in the early phase after abstinence. To clarify the question as to whether the degree of liver damage is of importance for possible changes in function of the adrenal system, the investigations were carried out in one group of patients with alcoholic fatty liver and another with liver cirrhosis. With a view to detecting possible changes in catecholamine metabolism, the excretion of the catecholamines and vanillylmandelic acid in 24-hour urine was also measured.

\section{Method and Material}

\section{Patients}

Thirty patients with chronic alcohol abuse were studied. In 16 of these patients ( 14 men and 2 women), a fatty liver had been verified histologically. In addition to fatty liver, three patients also had signs of the beginning right heart failure, while two other patients had duodenal ulcers. The remaining 14 patients (12 men and 2 women) had cirrhosis of the liver, the diagnosis of this group of patients being based on histologic findings and/or (mainly) on typical clinical and biochemical findings. All these patients had oesophageal varices, and six patients also had ascites. Five patients were treated with digoxin and diuretics, while three patients received antacids and $\mathrm{H}_{2}$-receptor antagonists. All the patients were admitted to hospital at least 4 days prior to the start of the study. At the time of the investigations, there was no evidence of withdrawal symptoms. In the last weeks prior to the study none of the patients showed any symptoms of gastrointestinal bleeding or clinically manifest signs of chronic hepatic encephalopathy. All patients received vitamins. At least 4 days prior to the start of the investigations, no changes were made in medication.

Table 1 presents a synopsis of the age distribution and characteristic biochemical data of the patients on admission to hospital, and of the control group. For this purpose, 16 healthy volunteers (13 men and 3 women) with an alcohol consumption of less than $30 \mathrm{~g}$ per day were examined. Bicycle ergometry was carried out in each case in the afternoon after a period of at least two hours without food, the patients with fatty liver being subjected to loading between the 4th and 30th day (mean 11 \pm 8 days), and the patients with liver cirrhosis between the 4th and 38 th day (mean $11 \pm 9$ days) after admission to hospital.

\section{Bicycle ergometry}

Ten minutes before initiating loading a catheter was placed in a vein of the forearm, and before starting seated ergometry a sample of blood was drawn. Loading was effected on the bicycle ergometer, the load being increased by 25 watts at intervals of

Tab. 1. Distribution of age and characteristic clinical chemical parameters $(\overline{\mathbf{x}} \pm s)$ of the studied subjects.

\begin{tabular}{|c|c|c|c|c|c|c|c|}
\hline Diagnosis & $\mathrm{n}$ & $\begin{array}{l}\text { Age } \\
\text { (years) }\end{array}$ & $\begin{array}{l}\gamma \text {-Glutamyl- } \\
\text { transferase } \\
(\mathrm{U} / \mathrm{l})\end{array}$ & $\begin{array}{l}\text { Aspartate } \\
\text { amino- } \\
\text { transferase } \\
(\mathrm{U} / \mathrm{l})\end{array}$ & $\begin{array}{l}\text { Alanine } \\
\text { amino-- } \\
\text { transferase } \\
(\mathrm{U} / \mathrm{l})\end{array}$ & $\begin{array}{l}\text { Prothrombin } \\
\text { time } \\
(\% \text { of } \\
\text { normal) }\end{array}$ & $\begin{array}{l}\text { Serum } \\
\text { electrö- } \\
\text { phoresis } \\
\gamma \text {-globulin } \\
\text { fraction }\end{array}$ \\
\hline $\begin{array}{l}\text { Fatty liver } \\
\text { Cirrhosis } \\
\text { Control group }\end{array}$ & $\begin{array}{l}16 \\
14 \\
16\end{array}$ & $\begin{array}{l}44 \pm 7 \\
43 \pm 8 \\
44 \pm 8\end{array}$ & $\begin{array}{r}138 \pm 146 \\
212 \pm 288 \\
18 \pm 10\end{array}$ & $\begin{array}{r}41 \pm 48 \\
50 \pm 47 \\
. \quad 13 \pm 4\end{array}$ & $\begin{array}{l}42 \pm 60 \\
26 \pm 20 \\
16 \pm 8\end{array}$ & $\begin{array}{l}95 \pm 10 \\
67 \pm 19 \\
100\end{array}$ & $\begin{array}{l}0.188 \pm 0.06 \\
0.323 \pm 0.10 \\
0.123 \pm 0.02\end{array}$ \\
\hline
\end{tabular}


one minute, up to a maximum load of 100 watts. Blood was also drawn after 50 and 100 watts loading, and also in the 10th minute of the recovery phase, with the patient seated. The heart rate was determined from a continuously recorded ECG.

The plasma catecholamine concentrations were determined with the aid of a radioenzymatic single isotope derivative technique (6), the intra-assay variation coefficients for the determination of dopamine, adrenaline and noradrenaline lying between $5 \%$ and $8 \%$.

On the day after ergometry, 24-hour urine specimens were collected in plastic vessels containing $10 \mathrm{ml} 6 \mathrm{~mol} / 1 \mathrm{HCl}$. Aliquots were stored at $-25^{\circ} \mathrm{C}$ until analysed. The catecholamines in the urine were also determined by the radioenzymatic method (6), and the elimination of vanillylmandelic acid using the method described by Pisano (7). In order to compensate for any errors due to incomplete collection of 24-hour urine, the catecholamine and vanillylmandelic acid excretion was referred to the creatinine elimination. Creatinine was determined using a modified Jaffé reaction (8).

The statistical significance of the results of bicycle ergometry was tested with the aid of the t-test for independent samples. Significance calculations for catecholamine and vanillylmandelic acid excretions were carried out using the Wilcoxon test.

\section{Results}

At rest there are highly significant differences between the control group and the two groups of patients, with respect to adrenaline, noradrenaline, dopamine and heart rate (tab. 2). The mean concentration of adrenaline and noradrenaline in the plasma is greater in patients with alcoholic cirrhosis than in patients with fatty liver.
During ergometry, these differences in the catecholamine concentrations and the heart rate persisted (tab. 2). At a load of 50 watts, of all the parameters measured, only the heart rates of all three groups differ significantly from those at rest (in each case $p<0.0001$ ). With the exception of the dopamine and adrenaline concentrations, at 100 watts, all the parameters measured differ significantly from their initial values. In the 10th minute of the recovery phase, neither the catecholamine concentrations nor the heart rates can be differentiated statistically from the initial levels. However, at this time, the mean noradrenaline concentrations of both patient groups, as well as the mean concentration of adrenaline in the patients with alcoholic cirrhosis, show a tendency to be higher than the respective basal concentrations, even after the elapse of a period equivalent to 5 halflives.

At a load of 100 watts, the heart rate of the control group is identical with that of both groups of patients at 50 watts. At the same time, there is no difference between the mean adrenaline and noradrenaline concentrations of the control subjects and the patients with fatty liver. Even at rest, patients with alcoholic cirrhosis have significantly higher noradrenaline, adrenaline and dopamine concentrations $(p<0.01$, in each case) than normal subjects under a load of 100 watts. Figure 1 shows the distribution of the absolute figures for adrenaline, noradrenaline, dopamine and heart rate referred to the respective resting figure,

Tab. 2. Influence of physical exercise on the plasma concentrations of catecholamines and heart rate of 16 control subjects, 16 patients with fatty liver and 14 patients with alcoholic liver cirrhosis (mean and standard deviation).

\begin{tabular}{|c|c|c|c|c|c|c|c|c|c|c|c|c|c|}
\hline & & \multicolumn{3}{|c|}{$\begin{array}{l}\text { Adrenaline } \\
\text { (nmol/l) }\end{array}$} & \multicolumn{3}{|c|}{$\begin{array}{l}\text { Noradrenaline } \\
(\mathrm{nmol} / \mathrm{l})\end{array}$} & \multicolumn{3}{|c|}{$\begin{array}{l}\text { Dopamine } \\
(\mathrm{nmol} / \mathrm{l})\end{array}$} & \multicolumn{3}{|c|}{$\begin{array}{l}\text { Heart rate } \\
\left(\min ^{-1}\right)\end{array}$} \\
\hline & & $\begin{array}{l}\text { Chon- } \\
\text { trrol } \\
\text { sub- } \\
\text { jects }\end{array}$ & $\begin{array}{l}\text { Fatty } \\
\text { liver }\end{array}$ & Cirrhosis & $\begin{array}{l}\text { Con- } \\
\text { trol } \\
\text { sub- } \\
\text { jects }\end{array}$ & $\begin{array}{l}\text { Fatty } \\
\text { liver }\end{array}$ & Cirrhosis & $\begin{array}{l}\text { Con- } \\
\text { trol } \\
\text { sub- } \\
\text { jects }\end{array}$ & $\begin{array}{l}\text { Fatty } \\
\text { liver }\end{array}$ & Cirrhosis & $\begin{array}{l}\text { Con- } \\
\text { trol } \\
\text { sub- } \\
\text { jects }\end{array}$ & $\begin{array}{l}\text { Fatty } \\
\text { liver }\end{array}$ & Cirrhosis \\
\hline \multirow[t]{2}{*}{$\begin{array}{l}\text { Before physical } \\
\text { exercise }\end{array}$} & $\begin{array}{l}\overline{\mathbf{x}} \\
\mathbf{s}\end{array}$ & $\begin{array}{l}0.53 \\
0.15\end{array}$ & $\begin{array}{l}0.86 \\
0.38\end{array}$ & $\begin{array}{l}1.09 \\
0.30\end{array}$ & $\begin{array}{l}1.94 \\
0.62\end{array}$ & $\begin{array}{l}3.01 \\
1.20\end{array}$ & $\begin{array}{l}4.75 \\
1.73\end{array}$ & $\begin{array}{l}0.23 \\
0.08\end{array}$ & $\begin{array}{l}0.48 \\
0.26\end{array}$ & $\begin{array}{l}0.61 \\
0.22\end{array}$ & $\begin{array}{r}79 \\
8\end{array}$ & $\begin{array}{r}101 \\
14\end{array}$ & $\begin{array}{r}101 \\
13\end{array}$ \\
\hline & $\begin{array}{l}\text { p1 } \\
\text { p2 }\end{array}$ & & ++ & $\begin{array}{l}+++ \\
+\end{array}$ & & ++ & $\begin{array}{l}+++ \\
++\end{array}$ & & ++ & $\begin{array}{l}+++ \\
\text { n.s. }\end{array}$ & & ++ & $\begin{array}{l}+++ \\
\text { n.s. }\end{array}$ \\
\hline $50 \cdot$ watts & $\begin{array}{l}\dot{\bar{x}} \\
s\end{array}$ & $\begin{array}{l}0.50 \\
0.15\end{array}$ & $\begin{array}{l}0.85 \\
0.34\end{array}$ & $\begin{array}{l}1.24^{\circ} \\
0.50\end{array}$ & $\begin{array}{l}2.01 \\
0.59\end{array}$ & $\begin{array}{l}3.20 \\
1.36\end{array}$ & $\begin{array}{l}5.62 \\
2.44\end{array}$ & $\begin{array}{l}0.24 \\
0.08\end{array}$ & $\begin{array}{l}0.50 \\
0.27\end{array}$ & $\begin{array}{l}0.61 \\
0.24\end{array}$ & $\begin{array}{r}97 \\
8\end{array}$ & $\begin{array}{r}118 \\
14\end{array}$ & $\begin{array}{r}119 \\
14\end{array}$ \\
\hline \multirow[t]{2}{*}{100 watts } & $\begin{array}{l}\overline{\mathbf{x}} \\
\mathbf{s}\end{array}$ & $\begin{array}{l}0.69 \\
0.26\end{array}$ & $\begin{array}{l}1.20 \\
0.53\end{array}$ & $\begin{array}{l}1.85 \\
0.78\end{array}$ & $\begin{array}{l}3.00 \\
1.75\end{array}$ & $\begin{array}{l}4.85 \\
2.00\end{array}$ & $\begin{array}{l}7.78 \\
3.50\end{array}$ & $\begin{array}{l}0.26 \\
0.09\end{array}$ & $\begin{array}{l}0.61 \\
0.30\end{array}$ & $\begin{array}{l}0.75 \\
0.39\end{array}$ & $\begin{array}{r}113 \\
13\end{array}$ & $\begin{array}{r}141 \\
16\end{array}$ & $\begin{array}{r}142 \\
15\end{array}$ \\
\hline & $\begin{array}{l}\text { p1 } \\
\text { p2 }\end{array}$ & & ++ & $\begin{array}{l}+++ \\
++\end{array}$ & & ++ & $\begin{array}{l}+++ \\
++\end{array}$ & & +++ & $\begin{array}{l}+++ \\
\text { n.s. }\end{array}$ & & ++ & $\begin{array}{l}+++ \\
\text { n.s. }\end{array}$ \\
\hline $\begin{array}{l}10^{\text {th }} \text { min of } \\
\text { recovery phase }\end{array}$ & $\begin{array}{l}\bar{x} \\
s\end{array}$ & $\begin{array}{l}0.44 \\
0.14\end{array}$ & $\begin{array}{l}0.84 \\
0.31\end{array}$ & $\begin{array}{l}1.32 \\
0.55\end{array}$ & $\begin{array}{l}1.85 \\
0.59\end{array}$ & $\begin{array}{l}3.37 \\
1.39\end{array}$ & $\begin{array}{l}6.05 \\
2.90\end{array}$ & $\begin{array}{l}0.24 \\
0.08\end{array}$ & $\begin{array}{l}0.53 \\
0.28\end{array}$ & $\begin{array}{l}0.66 \\
0.20\end{array}$ & $\begin{array}{r}83 \\
8\end{array}$ & $\begin{array}{l}99 \\
15\end{array}$ & $\begin{array}{r}105 \\
15\end{array}$ \\
\hline
\end{tabular}

p1 Control vs. patients with fatty liver resp. alcoholic cirrhosis.

p2 Patients with fatty liver vs. patients with alcoholic liver cirrhosis

${ }^{*} \mathrm{p}<0.05,{ }^{* *} \mathrm{p}<0.01,{ }^{* * *} \mathrm{p}<0.001$. 


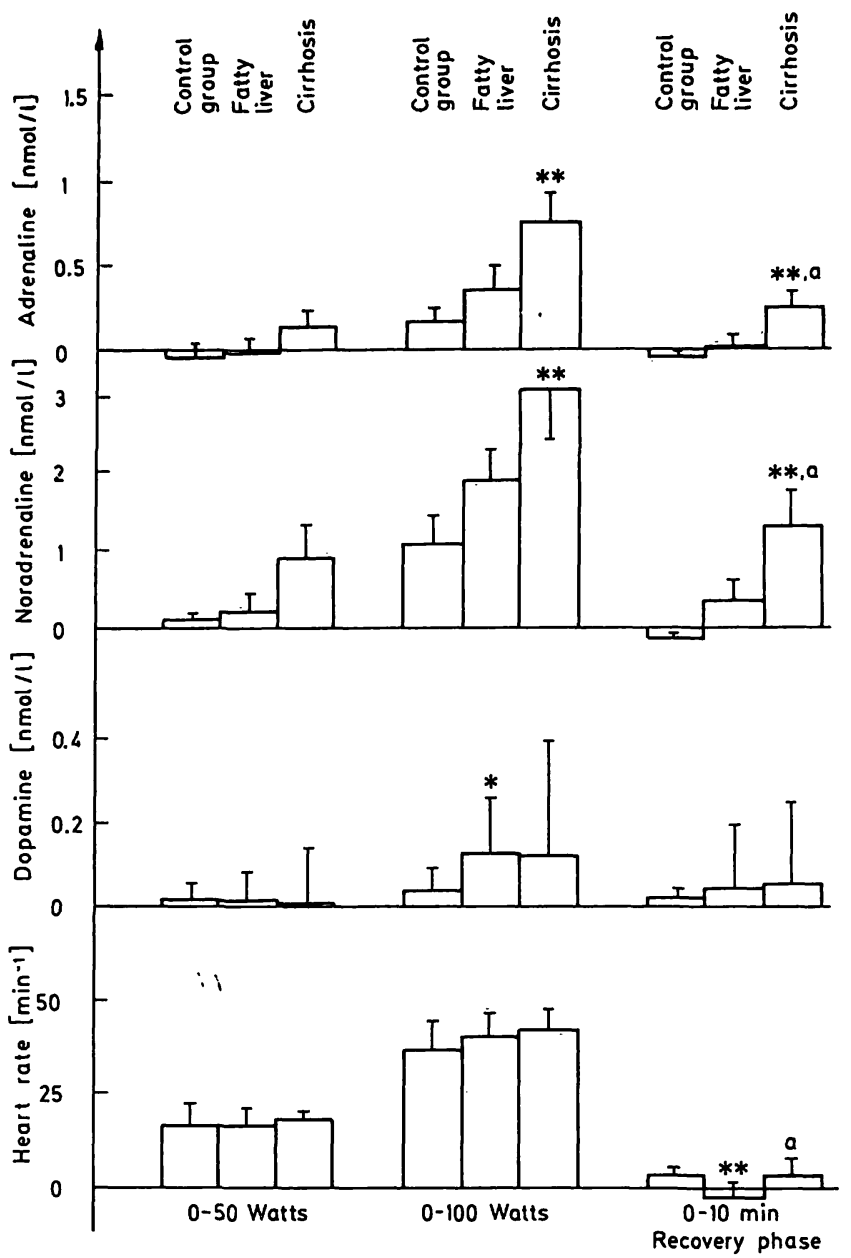

Fig. 1. Concentrations of adrenaline, noradrenaline, dopamine and heart rate referred to the respective resting value, during increasing ergometric loading $(0,50,100$ watts, $10 \mathrm{~min}$ recovery) in 16 normal subjects, 16 patients with alcoholic fatty liver, and 14 patients with alcoholic cirrhosis.

The data represent mean values and mean standard deviations; $*, * *$ identify significant differences from the control group, with $p<0.05$ or $p<0.001$, respectively; a identifies significant differences between patients with fatty liver and cirrhosis, with $\mathrm{p}<0.05$.

during ergometry. With the exception of the fall in heart rate in the recovery phase in patients with fatty liver, the changes in the heart rate are identical in all three groups. At 50 watts loading, patients with alcoholic cirrhosis showed statistically significant increases only in noradrenaline ( $p<0.05$ ), when compared with controls. At 100 watts loading, both adrenaline and noradrenaline were increased $(p<0.01$ each). Dopamine was increased $(p<0.05)$ in patients with fatty liver.

If, instead of absolute figures, the percentage deviations in catecholamine concentrations under exercise vis-á-vis the respective resting concentrations are compared, the differences between the 3 groups investigated are found to be considerably less marked . and no longer statistically differentiable. Thus, for example, under a load of 100 watts, the noradrenaline concentrations increased by $54 \% \pm 77 \%$ in the normal subjects, and by $71 \% \pm 63 \%$ and $65 \% \pm$ $46 \%$, respectively, in patients with fatty liver and alcoholic cirrhosis.

During stepwise ergometric loading, adrenaline and noradrenaline show an almost parabolic increase in relation to heart rate (fig. 2), the curve being steeper in the case of the patients. The ratio of noradrenaline to adrenaline at rest is $3.6 \pm 1.3,3.5 \pm 1.4$ and 4.0 \pm 1.2 for the control group, patients with fatty liver, and those with alcoholic cirrhosis, the differences being non-significant. The ratio, noradrenaline to adrenaline, remains constant in each group throughout increasing ergometric loading.

The amount of adrenaline and noradrenaline excreted in both patient groups in relation to the serum concentrations is only moderately elevated in all groups (fig. 3). Statistically, the three groups show no differences in the mean amount of adrenaline and

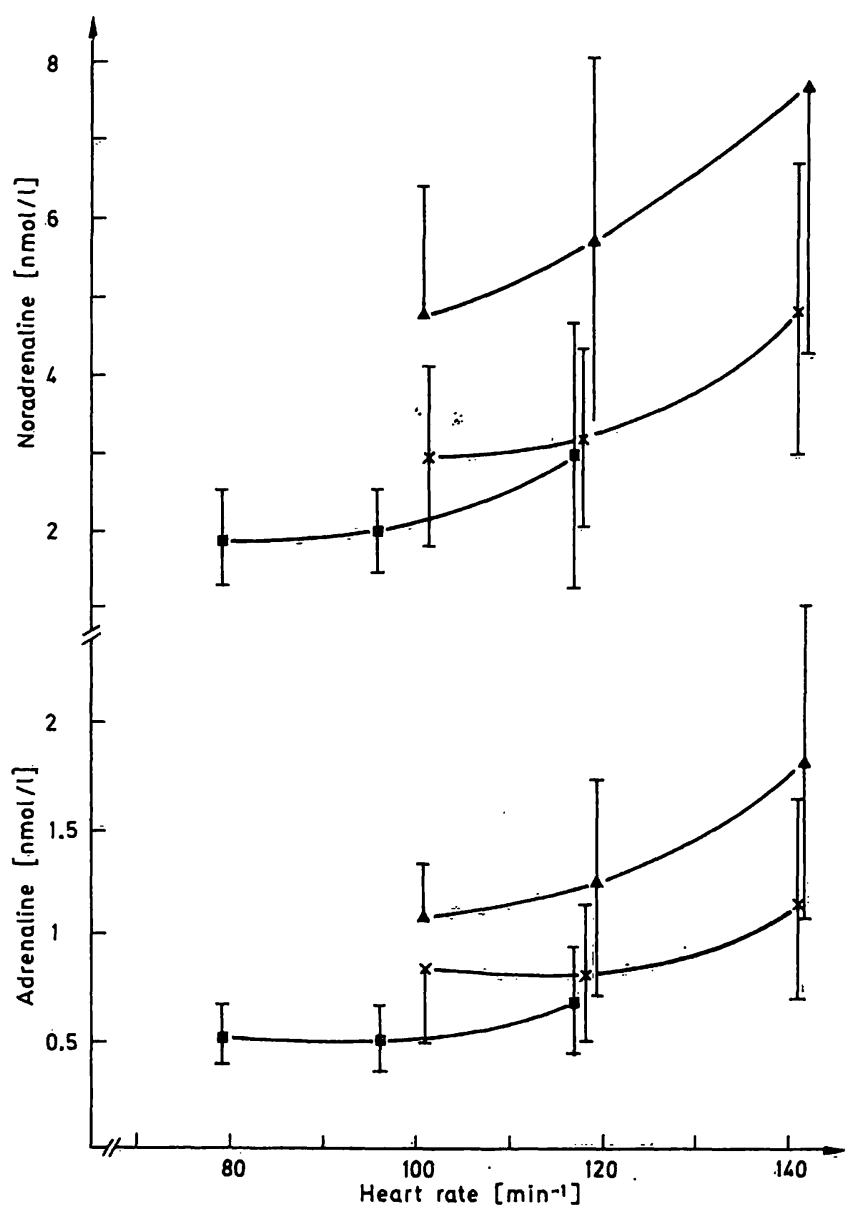

Fig. 2. Concentrations of noradrenaline and adrenaline during increasing ergometry loading $(0,50,100$ watts) in relationship to the heart rate in 16 normal subjects (घ), 16 patients with alcoholic fatty liver $(x)$, and 14 patients with alcoholic cirrhosis $(\Lambda)$ (means \pm standard deviation). 


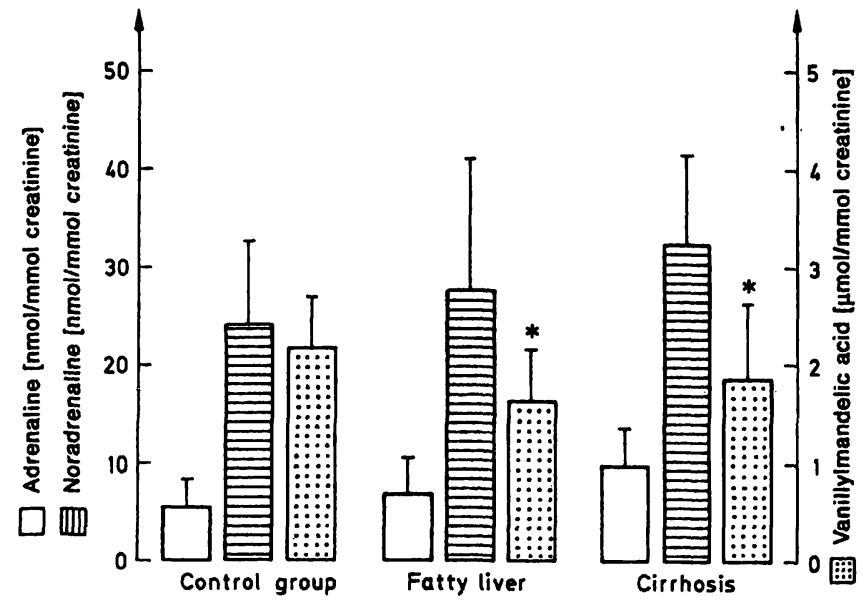

Fig. 3. Excretion of adrenaline, noradrenaline and vanillylmandelic acid in the control group $(n=16)$, and in patients with fatty liver $(n=12)$ or alcoholic cirrhosis $(n=9)$. The data represent mean values with respective standard deviations. Significant differences between the control group and the patients are found only for vanillylmandelic acid excretion (* $\mathrm{p}<0.002$ ).

noradrenaline excreted, although the patients with alcoholic cirrhosis do reveal a tendency towards higher catecholamine elimination than to patients with fatty liver, or controls. In contrast, the mean excretion of vanillylmandelic acid in patients with cirrhosis $(1.87 \pm 0.7 \mu \mathrm{mol} / \mathrm{mmol}$ creatinine $)$ and also in the patients with fatty liver $(1.64 \pm 0.5 \mu \mathrm{mol} / \mathrm{mmol}$ creatinine) is significantly reduced in comparison to the controls $(2.19 \pm 0.5 \mu \mathrm{mol} / \mathrm{mmol}$ creatinine) ( $\mathrm{p}$ $<0.002$ in each case). With respect to the excretion of vanillylmandelic acid, no statistically significant differences are found between the two groups of patients.

\section{Discussion}

The present result show that resting plasma catecholamine concentrations are already increased in chronic alcoholics without advanced liver disease. They further increase in subjects with alcohol-induced liver cirrhosis. The latter finding is in accordance with results obtained by other authors in patients with advanced alcoholic or non-alcoholic cirrhosis $(9-11)$. In contrast to the increased catecholamine concentrations in the alcoholics with only mild signs of liver disease, patients with non-alcoholic cirrhosis with moderate portal hypertension and without ascites had normal values (12).
The possible causes of this increase in concentration of plasma catecholamines are manifold, for example, an increase in synthesis, a reduction in re-uptake, impaired metabolism or reduced clearance (9). Accompanying diseases or drugs can also influence these mechanisms. Thus, it is wellknown that patients with heart failure (13) or duodenal ulcers (14) have elevated levels of adrenaline in the plasma, while diuretics have only little effect on plasma and urine catecholamines (15). Patients with alcoholic liver disease and cardiac insufficiency or duodenal ulcers were included in the investigations, since their catecholamine concentrations did not differ from those of the remaining patients (since they had no influence on the results of the investigations). Although excretion in 24-hour urine in patients with alcoholic liver disease does not differ significantly from that of the control group, it does increase as liver damage progresses. Thus, it is unlikely that impaired renal clearance is the cause of the increase in concentration.

Indeed, as Burghardt et al. (9) and Henriksen et al. $(10,11)$ were recently able to show, cirrhosis of the liver with a wide range of aetiologies is associated with an increase in renal secretion of noradrenaline. These data show that elevated plasma catecholamine concentrations do not always indicate stimulation of the sympathoadrenal system as a whole. For this reason, the plasma concentrations were measured not only at rest, but also under exercise conditions. Here, it was revealed that the catecholamine concentrations increase under exercise conditions in proportion to the basal concentrations. In relation to the initial levels, the increases in catecholamine concentrations are identical in all three groups. The heart rate also behaves in a similar manner. In the patient groups with higher resting values, the increase under exercise conditions was greater than in the control group. But increases in heart rate after infusion of catecholamines are observed only when noradrenaline concentrations are ten times higher, and adrenaline concentrations four times higher than the respective mean basal concentrations (16). Since such high catecholamine concentrations were not observed in the patients, the elevated catecholamine levels and heart rates observed at rest and under exercise can probably not be explained on the basis of an isolated renal and adrenal secretion of catecholamines. Instead, it must be assumed that in these patients the neuronal activity of the sympathetic nervous system is also raised. In consequence of an increase in transmitter secretion in the synapses and, possibly, also of a reduction in re-uptake into the adrenergic neurons, increased amounts of noradrenaline enter the circulation. This augmentation of increased activity of the 
sympathoadrenal system as a whole is underscored by the fact that the ratio of noradrenaline to adrenaline concentration is the same at rest and during bicycle ergometry, although the noradrenaline and adrenaline are from different sources.

An epidemiological study of more than 80000 people revealed a significant increase in the average blood pressure values as a function of the mean alcohol consumption (17). This increase in blood pressure values was independent of age, sex, race or other risk factors such as cigarette smoking, adiposity and coffee consumption. The augmented activity of the sympathoadrenal system suspected on the basis of the results of the present investigation, may be considered a leading cause of elevated blood pressure in persons with a high alcohol consumption.

A striking observation is that, in comparison with the greatly elevated plasma catecholamine con-

\section{References}

1. Teschke, R. \& Lieber, C. S. (1981) Alkohol und Organschäden: Epidemiologische, klinische, biochemische und therapeutische Aspekte. Witzstrock-Verlag.

2. Giacobini, E., Izikowitz, S. \& Wegmann, A. (1960) Experientia 16, 467.

3. Brohult, J., Levi, L. \& Reichard, H. (1970) Acta Med. Scand. 188, 5-13.

4. Ogata, M., Mendelsohn, J. M., Mello, N. K. \& Majchrowicz, E. (1971) Psychosomatic Medicine 33, 159-180.

5. Wright, J. (1978) Clin. Endocrinol. Metab. 7, 351-368.

6. Ratge, D., Baumgardt, G., Knoll, E. \& Wisser, H. (1983) Clin. Chim. Acta 132, 229-243.

7. Pisano, J. J., Crout, J. \& Abraham, D. (1962) Clin. Chim. Acta 7, 285-292.

8. Knoll, E., Rebel, R. C. \& Wisser, H. (1978) J. Clin. Chem. Clin. Biochem. 20, 239-244.

9. Burghardt, W., Wernze, H. \& Schaffrath, I. (1982) Acta Endocrinol. 99 (Suppl. 246), 100-101. centrations, catecholamine excretion is only moderately elevated, and that there is a significant reduction in the excretion of vanillylmandelic acid as compared with the control group. The latter finding was also reported by Ogata et al. (4) in patients with chronic alcohol abuse, and by Davis et al. (18) after acute administration of alcoholf, a simultaneous increase in 3-methoxy-4-hydroxyphenyl glycol also being observed. Other authors (2), however, found no difference in the renal excretion of adrenaline and noradrenaline in chronic alcoholics during abstinence. The possible cause of a change in the relationship of vanillylmandelic acid to 3-methoxy-4hydroxyphenyl glycol in acute alcohol administration may be the elevation in the hepatic NADH/NAD ${ }^{+}$ quotient due to catabolism of the alcohol. However, this cannot explain the results of the present investigation, since the patients were not acutely exposed to alcohol.

10. Henriksen, J. H., Ring-Larsen, H. \& Christensen, N. J. (1984) J. Hepatol. 1, 55-65.

11. Henriksen, J. H., Christensen, N. J. \& Ring-Larsen, H. (1981) Clin. Physiol. 1, 293-304.

12. Henriksen, J. H., Ring-Larsen, H., Kanstrup, I. L. \& Christensen, N. J. (1984) Gut 25, 1034-1043.

13. Goldstein, D. S. (1981) Am. J. Cardiol. 48, 1147-1154.

14. Järhult, J., Angeras, U., Famèbo, L.-D., Graffner, H., Hamberger, B. \& Uvnäs-Moberg, K. (1984) Scañd. J. Gastroenterol. 19 (Suppl. 89), 137-141.

15. Schiff, H., Weidmann, P., Meier, A. \& Ziegler, W. H. (1981) Klin. Wochenschr. 59, 837-844.

16. Cryer, P. E. (1980) N. Engl. J. Med. 303, 436-444.

17. Klatsky, A. L., Friedman, G. D., Siegelaub, A. B. \& Gérard, M. J. (1977) N. Engl. J. Med. 296, 1194-1200.

18. Davies, V. E., Brown, H., Huff, J. A. \& Cashaw, J. L. (1967) J. Lab. Clin. Med. 69, 787-799.

Prof. Dr. Dr. H. Wisser

Abteilung für Klinische Chemie

Robert-Bosch-Krankenhaus

Auerbachstr. 110

D-7000 Stuttgart 50 